Apidologie, 1988, 19 (1), 25-36

\title{
THE COMBS OF HONEYBEES AS COMPOSITE MATERIALS
}

\author{
H.R. HEPBURN ${ }^{(*)}$ and S.P. KURSTJENS \\ Department of Physiology, University of the Witwatersrand, Johannesburg, South Africa
}

\begin{abstract}
SUMMARY
Mechanical changes in the combs of the African honeybee, $A . m$. scutellata, in relation to maturation and temperature were measured. Combs ranged in colour from white to brown and varied in silk content from 0 to $34 \%$.

New brood comb proceeds from a single-phase material, pure wax, to a fibre-reinforced composite. Fibroin, a crystalline and hygroscopic protein, is spun randomly on the cell walls making them planar isotropic. This silk fraction is mechanically constant between $25^{\circ} \mathrm{C}$ and $45^{\circ} \mathrm{C}$.

Comb wax is an isotropic plastic having no unique mechanical constants. The stiffness, strength and fracture energy of comb wax decreased with increasing temperature. When silk is present in comb cell walls, making them a two-phase material, comb strength and stiffness are greatly enhanced. Fibroin thus greatly contributes to the mechanical integrity of combs.
\end{abstract}

Mature brood combs are a compromise between the very different materials, wax and silk, which when combined produce a structure with new properties that differ from its individual constituents.

\section{INTRODUCTION}

The honeybee nest contains areas for the storage of nectar and pollen and for the rearing of brood. While wax is the basic building material for the nest, with continued use the combs become modified by the additions of silk and propolis. Thus, much of the honeybee nest gradually changes from a single to a composite material. Some of the material properties of the individual phases of the honeybee nest have now been characterized (HEPBuRN, 1986), but their possible contributions to the composite have remained unexplored. We report the results of some mechanical measurements of combs and trace the material development of the nest from monophasic wax to the fully developed composite.

$\left(^{*}\right)$ Present address : Department of Zoology and Entomology, Rhodes University, Grahamstown, 6140, South Africa. 


\section{MATERIALS AND METHODS}

All of the combs used in this study were collected on the Transvaal highveld from the nests of the African honeybee, Apis mellifera scutellata, that were either feral or kept in hives without any beeswax foundation. The individual combs ranged in colour from white through light brown to dark, brownish black. Colour is roughly correlated with age and use, in the case of brood combs, as evidenced by the mass ratio of silk to wax and the numbers of layers of silk present in the cell wall.

Tensile test specimens were prepared by cutting flat slabs from individual cell walls. Some of these were tested in their natural state. Others were soaked in chloroform to remove the beeswax from the sheets of silk, a procedure which leaves the cleaned silk sheets intact and separable. These two preparations were cut to uniform length $(1,4 \mathrm{~mm})$ and width $(0,6 \mathrm{~mm})$ such that gauge length was parallel to the long axis of the intact cell. Other tests were performed to establish whether or not cell walls exhibit planar isotropy and in those cases specimens were cut at the required angles. Specimens of comb were prepared by cutting large rectangles, about 15 by 8 cells. The rectangles were then carefully cut to form two isoceles contiguous at their apices. In the final specimen, the bases of the isoceles were five cells wide and their apices one.

Whole cell wall and cell wall silk samples were mounted on shims of polyester as previously described (Kurstuens et al., 1985). The intact comb samples were held for testing in solid wooden grips patterned in female form to accommodate the male test specimens. All tensile tests were performed on the extensometer of JoFFE and HePBuRn (1974) at an extension rate of $53.6 \times 10^{-6} \mathrm{~m} \mathrm{~s}{ }^{-1}$. A temperature controlled water bath was fitted to the lower grip and all specimens were submerged before and during testing. It is assumed that the water had no effects on the deformation behaviour of the waxes. Silk, however, is extremely hygroscopic (DENHAM and LoNSDALE, 1933) so that immersion in water obviated differences that may otherwise have arisen with natural changes in relative humidity. The test temperatures, 25 to $45^{\circ} \mathrm{C}$, were meant to reflect a range that might impinge on the honeybee nest in nature.

The force-time curves obtained from the tensile tests were transformed into their corresponding stress-strain relationships which yielded engineering values for stress, strain, stiffness and energy to fracture (Hepburn and Chander, 1980). These conventions were only applicable to specimens of cell walls containing wax. Because there is no measured value for silk denier, nor can the cross-sectional area of a broken sheet of silk be determined with any confidence, values for stress and stiffness are given as relative, in units of $\mathrm{N} \mathrm{mm}^{-1}$ and not $\mathrm{N} \mathrm{mm}^{-2}$. Values for large pieces of comb are also given as relative owing to the complexity of the fracture cross section.

\section{RESULTS AND DISCUSSION}

\section{The Elastic Fraction (Silk)}

Just before pupation honeybee larvae cover the walls of their cells with silk (Huber, 1814 ; ARNHART, 1919), playing out the fibres randomly so that by the end of the spinning the walls are covered by thin sheets in which the individual fibrils are readily discernible $\left(\mathrm{J}_{\mathrm{AY}}, 1964\right)$. Subsequently the larvae produce, from the anus, a colourless pollen-free material and then a yellow pollen-bearing one, both of which are applied in turn to the silk base (VerLICH, 1930 ; JAY, 1964). Nothing further is known of these substances, but they invite the analogy of a size as in paper manufacture. 
Successive generations of brood apply more silk to the walls, the cells become smaller, and the mass ratio of silk to wax greater (CHAUviN, 1962). Thus, old brood combs are heavily impregnated with silk which is inseparable from the wax except by chemical or heat treatments. The development and maturation of brood comb proceeds from a single-phase material, pure white wax, to a coloured fibre-reinforced two-phase composite. The physical significance of these observations can be illustrated by comparing the properties of native fibroin, wax-free sheets of silk, silk-free wax, propolis and the final wax-silk composite.

Honeybee silk is an alpha-helical fibroin (Rudall, 1962) the micelles of which form a four-stranded array of coiled coils parallel to the fibre axis (AtKINS, 1967). Honeybee fibroin is crystalline relative to other insect silks (Lucas and Rudall, 1968) but the hydrated fibre is only half as stiff as dry ones although they are equal in strength (HEPBURN et al., 1979). The fibroin is hygroscopic and when solvated is highly distensible largely owing to its conformation (LuCAS and RuDALL, 1968). These structurally undesirable properties of the fibroin are largely suppressed by the cocoon-spinning larvae.

The fact that the silk is impacted in the wax of the cell wall, possibly aided by the anal secretions, immediately checks the susceptibility of fibroin to solvation. Thus it is likely that inter-micellar friction is enhanced (WARWICKER, 1960) and the conformational change restricted (RUDALL, 1962), effects consistent with a good stiffness and reduced distensibility (HEPBURN et al., 1979). That the silk fibres are spun and randomly arranged in the cell wall overcomes the basic anisotropy of the material : dewaxed sheets of cocoon silk are planar isotropic on tensile deformation.

TABL. 1. - Tensile mechanical properties of dewaxed sheets of honeybee cocoon silk.

\begin{tabular}{c|c|c|c|c}
\hline \hline Temperature & $\begin{array}{c}\text { Relative Tensile } \\
\text { strength }\end{array}$ & Breaking strain & Relative Stiffness & Work \\
\hline${ }^{\circ} \mathrm{C}$ & $\left(\mathrm{Nmm}^{-1}\right)$ & $(\%)$ & $\left(\mathrm{Nmm}^{-1}\right)$ & $\left(\mathrm{MJm}^{-3}\right)$ \\
\hline $25^{\circ}$ & $32 \pm 16$ & 98 & $33 \pm 14$ & $29 \pm 20$ \\
$30^{\circ}$ & $32 \pm 18$ & 81 & $40 \pm 13$ & $28 \pm 23$ \\
$35^{\circ}$ & $26 \pm 10$ & 85 & $31 \pm 8$ & $22 \pm 14$ \\
$40^{\circ}$ & $39 \pm 17$ & 105 & $37 \pm 14$ & $38 \pm 22$ \\
$45^{\circ}$ & $43 \pm 20$ & 106 & $41 \pm 14$ & $48 \pm 30$ \\
\hline
\end{tabular}

For each value, $\mathbf{n}=10$.

Natural variations in the temperature of honeybee nests invite a consideration of silk behaviour accordingly. The independence of the mechanical pro- 
perties of sheets of honeybee fibroin deformed in tension at a fixed rate between 25 and $45^{\circ} \mathrm{C}$ are given in Table 1 . Sheets of silk maintain the same relative strength and distensibility. Consequently, changes in stiffness or the energy to fracture the sheet, an index of its relative workability, were not observed. The tensile properties of silk sheets over this range of temperatures are in sharp contrast to those of pure wax (Table 2 and HePBurn et al., 1983), propolis (HePBurn and KurStJens, 1984) and the wax-silk composite brood combs (Table 2).

TABL. 2. - Tensile mechanical properties of white comb wax walls with no silk and brown comb walls of $34 \%$ silk.

\begin{tabular}{l|c|c|c|c|c}
\hline \hline \multicolumn{1}{c|}{ Specimen } & $\begin{array}{c}\text { Tempera- } \\
\text { tures }{ }^{\circ} \mathrm{C}\end{array}$ & $\begin{array}{c}\text { Tensile strength } \\
(\mathrm{MPa})\end{array}$ & $\begin{array}{c}\text { Breaking strain } \\
(\%)\end{array}$ & Stiffness (MPa) & Work $\left(\mathrm{MJm}^{-3}\right)$ \\
\hline white comb & $25^{\circ}$ & $1.0 \pm 0.1$ & $12 \pm 1$ & $9.1 \pm 0.1$ & $7.4 \pm 1.7$ \\
wax & $30^{\circ}$ & $1.5 \pm 0.4$ & $8 \pm 1$ & $18.4 \pm 5.4$ & $5.5 \pm 1.5$ \\
& $35^{\circ}$ & $1.1 \pm 0.4$ & $7 \pm 1$ & $17.5 \pm 6.1$ & $3.8 \pm 1.7$ \\
& $40^{\circ}$ & $0.4 \pm 0.1$ & $6 \pm 2$ & $6.8 \pm 2.1$ & $9.4 \pm 3.4$ \\
brown comb & $45^{\circ}$ & $0.1 \pm 0.03$ & $5 \pm 1$ & $2.7 \pm 1.1$ & $2.6 \pm 3.7$ \\
with silk & $25^{\circ}$ & $4.3 \pm 0.5$ & $16 \pm 4$ & $29.9 \pm 10$ & $20 \pm 4$ \\
& $30^{\circ}$ & $4.4 \pm 1.1$ & $15 \pm 1$ & $30.5 \pm 10.2$ & $16 \pm 4$ \\
& $35^{\circ}$ & $4.6 \pm 1.1$ & $16 \pm 3$ & $29.6 \pm 7.9$ & $17 \pm 5$ \\
& $40^{\circ}$ & $3.0 \pm 0.9$ & $14 \pm 3$ & $22.9 \pm 8.5$ & $10 \pm 2$ \\
& $45^{\circ}$ & $2.1 \pm 0.4$ & $13 \pm 2$ & $16.7 \pm 4.5$ & $7 \pm 3$ \\
\hline
\end{tabular}

For each value, $\mathrm{n}=6$.

In addition to crystal structure, white comb wax is also affected by the presence of a protein fraction (KuRSTJENs et al., 1985). This material is present, quite apart from silk, in both wax scales and in newly constructed combs. In both cases, this uncharacterized protein is positively associated with enhanced stiffness in both scales and comb. Nothing is known of the molecular behaviour of this protein or how it might contribute to the stiffness of wax. To have assigned this protein to the elastic fraction is somewhat gratuitous.

\section{The Plastic Fractions (Wax and Propolis)}

The beeswax of comb is an isotropic plastic having no unique mechanical constants : stiffness, strength and extensibility all vary with the rate of deformation and with the temperature (HePBurn et al., 1983; Hepburn and KuRSTJENS, 1984). Silk-free comb walls of white wax, for example, exhibited an order of magnitude difference between 25 and $45^{\circ} \mathrm{C}$. Such wax failed plastically at ever lower extensions with increasing temperature (Table 2). Similarly, stiffness and fracture energy decreased as the temperature rose (Table 2). 
At first sight, these characteristics of native wax appear at variance with those of refined wax. Crystal texture is observable in annealed wax (BREwSTER, 1815) an effect enhanced by temperature and associated with increased strength in extruded wax ribbons (Woog and YanNaquis, $1935 ; 1936 a, b$ ). Mechanical deformation in general tends to augment crystal texture in refined wax (Schmidt, 1941: Schoening, 1980). Woog and Yannaquis (1935, $1936 \mathrm{a}, \mathrm{b})$ also reported that untreated specimens of comb wax stored at $38{ }^{\circ} \mathrm{C}$ were more textured than others kept at $15^{\circ} \mathrm{C}$.

By analogy to refined wax, Woog and YannaQuis (1935, 1936a, b) implied that comb strength might increase with the warmth of the honeybee nest in time. Against this, they also showed that brown combs were less textured than either white or yellow ones. It has not yet been possible to assess how crystal texture changes in vivo in a systematic way nor, therefore, to assess its possible contribution to mechanical behaviour. However, the low order of texture in native wax vis-a-vis that of manipulated samples of refined beeswax (Schoening, 1980) mitigates against any large contribution by crystal texture to the performance of the latter.

There are other, far from subtle, changes in combs. Newly formed combs of white wax soon yellow, pass through shades of brown and finally become almost black with age. HUBER (1814) suggested that white and yellow combs differed mechanically and that propolis (not the source of yellowness), added to wax, colours it darkly. Inasmuch as propolis is a common constituent in dark combs (Chauvin, 1962 ; Tischer, 1962), its properties are relevant to the discussion. The tensile behaviour of propolis is, like beeswax, entirely plastic and stiffness, strength, and workability all decrease between 25 and $45{ }^{\circ} \mathrm{C}$ (Hepburn and Kurstjens, 1984). Over this range of temperatures, propolis at its strongest just matches beeswax at its weakest.

To summarize, the mechanical integrity of white comb wax and propolis is diminished with increasing temperature. Their properties are in contrast to those of honeybee silk (Tables 1 and 2; Hepburn et al., 1983 ; HePBurn and KURSTJENS, 1984). We have considered the behaviours of the separate elements that may constitute the nests of honeybees. Mature combs, however, are composites of two or more of these elements and can be expected to exhibit different characteristics to which we now turn.

\section{The Composite Comb}

The tensile behaviour of brood comb, a two-phase composite material, is well illustrated by comparing the walls of silk-free white comb with similar specimens of brood comb having a substantial amount (34\%) of silk (Table 2). Between 25 and $45{ }^{\circ} \mathrm{C}$, both preparations decreased in strength and 
very rapidly so, near $40^{\circ} \mathrm{C}$. The fibre reinforcement of silk in the propolisbearing brown comb was an order of magnitude stronger than white wax alone; the former considerably stronger than the latter at all of the assay temperatures. On average, the breaking strain in the reinforced comb was double that of white wax (Table 2). Combined with the greater loads required to break combs reinforced with silk, this greater distensibility provides a safety factor of 1 over that of white comb wax.

The contribution of the silk fibre to the composite is also reflected in stiffness, a measure of the initial resistance of the material to deformation. A decrease in stiffness with rising temperature was common to both white wax and the composite comb. However, when the composite was least tenacious it was comparable in stiffness to white comb wax when it was unyielding (Table 2). The energy fracture for reinforced comb and white wax was similar in trend to that of stiffness. The very rapid rate of decline in the structural integrity of comb wax with rising temperature was thus greatly moderated by reinforcement with fibroin (Table 2).

The behaviour of composite comb (Table 2) was specific for specimens of brood comb having $34 \%$ silk by weight. However, the mass ratio of silk to wax changes with successive generations or brood cycles. Chauvin (1962) showed that, in a series of combs ranging from pale yellow to brownish black, the mass of wax per unit area of comb doubled, while that of silk increased from 2 to $42 \%$. So, while the absolute mass of wax increased over time, the relative amount of wax actually decreased. This occurred in addition to unspecifiable chemical changes associated with comb colour.

We have assessed the tensile performance of silk-bearing comb cell walls in relation to changing silk/wax ratios. The strength of such combs increased substantially on doubling the silk content (Fig. 1a) as did the extension to breaking (Fig. 1b). Because strength and extensibility change at virtually the same rate with increasing silk content, stiffness remained unchanged over a range of 17 to $37 \%$ silk content (Fig. 1c). However, the energy to fracture increased several-fold with increasing silk (Fig. 1d).

The significance of the above is evident : the greater the silk to wax ratio, the stronger the cell wall and the greater the energy required to break the material. However, the interactions between silk and wax are difficult to define. Because the silk fibres are randomly disposed in the plane of the cell wall, there may be large variations in the number of fibrils that participate in the deformation process.

Tests of whole combs provide data whose origins are obscured by complex specimen geometry. In our measurements, the loading vectors differed greatly from those operating on cell walls. In whole combs there was a small increase 

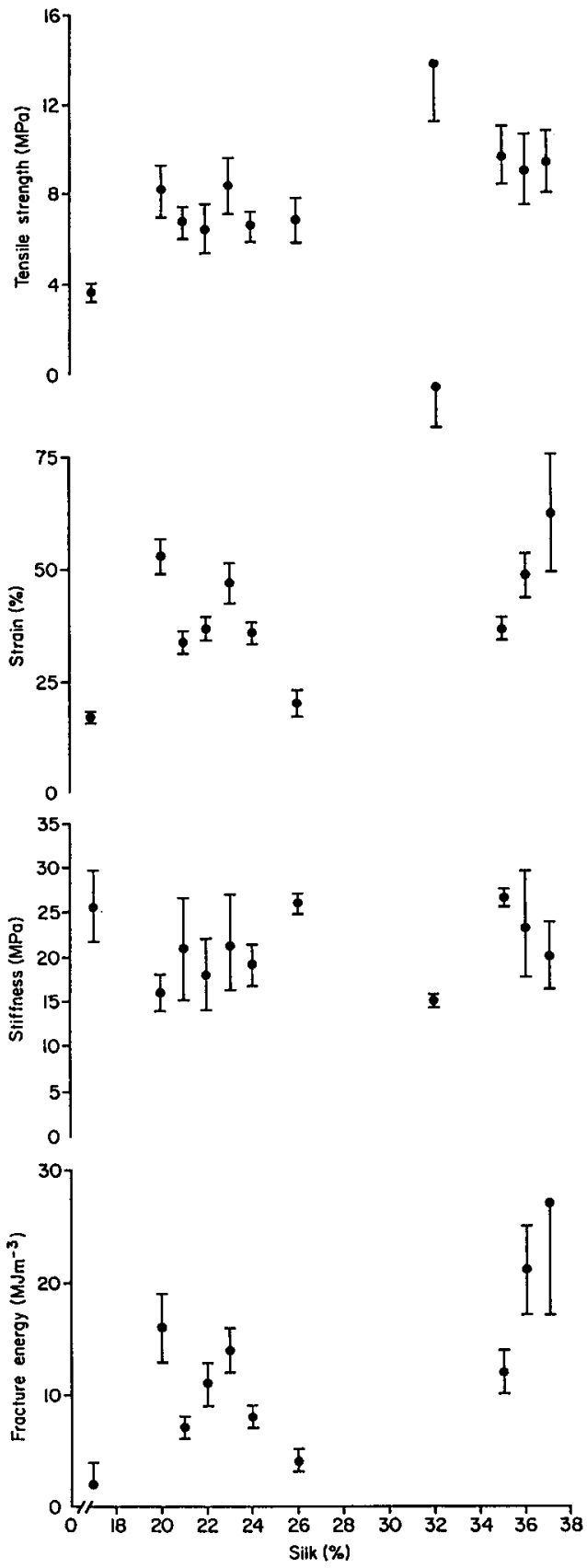

FIG. 1. - Mechanical behaviour of individual comb cell walls of differing silk content tested at $20^{\circ} \mathrm{C}$.

For each point, $n=6$. Means are given with SEM. (a) tensile strength. (b) extension to fracture. (c) stiffness. (d) energy to fracture. 

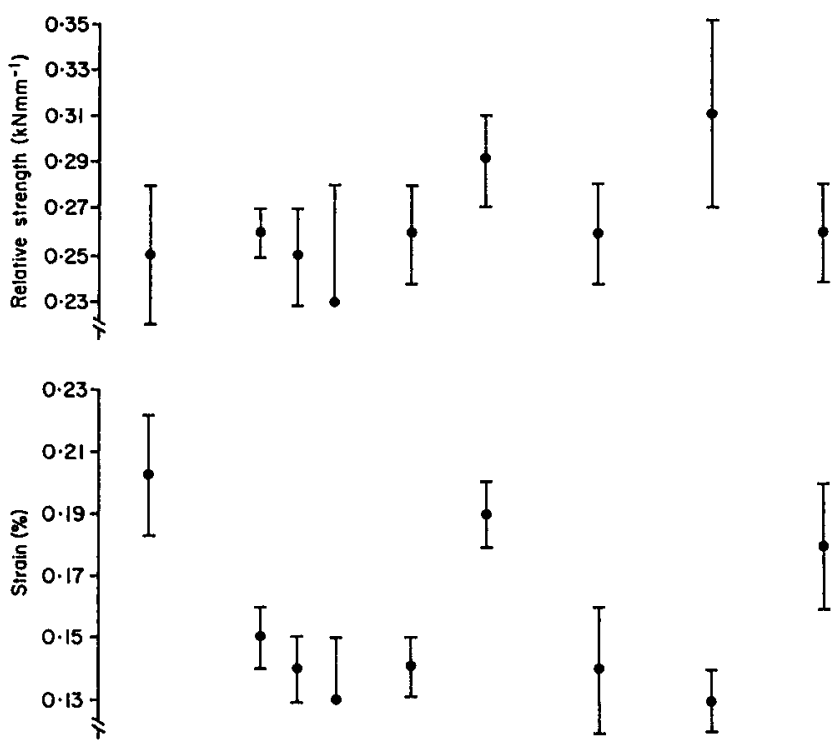<smiles>CC(C)CC(C)(C)C</smiles>

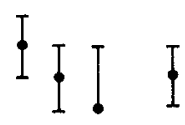

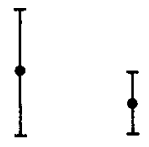

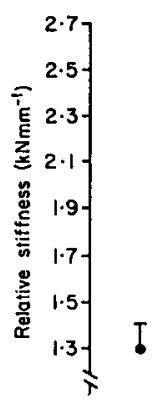

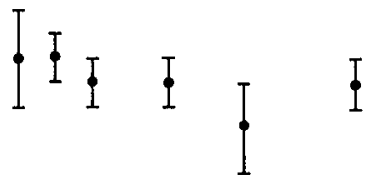

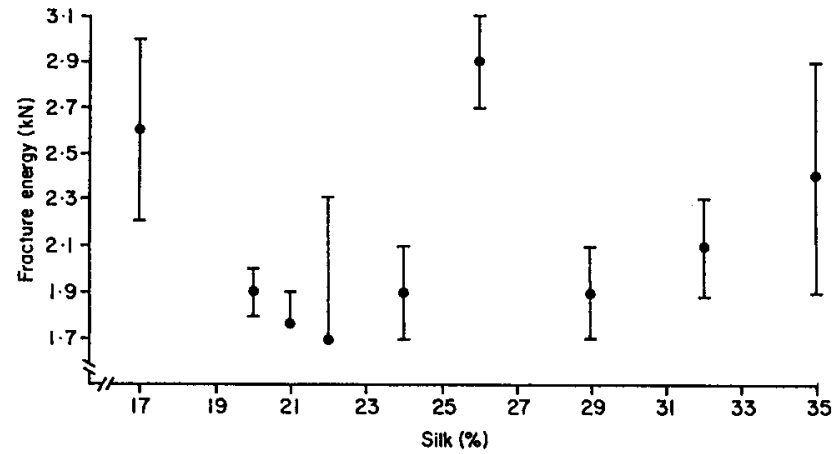

FIG. 2. - Mechanical behaviour of whole brood combs of differing silk content tested at $20^{\circ} \mathrm{C}$.

For each point, $n=6$. Means are given with SEM. (a) relative strength. (b) extension to fracture. (c) relative stiffness. (d) energy to fracture. 
in relative strength with increasing silk content (Fig. 2a) and a concomittant decrease in breaking strain (Fig. 2b) and increase in stiffness (Fig. 2c).

The large variations in the test results of whole comb (Figs. $2 \mathrm{a}$ to $2 \mathrm{c}$ ) were associated with gross differences in the fracture behaviour of the failed specimens. Within each silk percentage class, three modes of failure were observed. Some fractures were propagated intermurally, others intramurally, and in others combinations of both were observed. These modes of fracture are indicative of the gross structural heterogeneity of whole combs and are further reflected in the fracture energy characteristics of the specimens (Fig. 2d).

\section{CONCLUSIONS}

The honeybee nest contains areas for the storage of nectar and pollen and those for the rearing of brood, either in the same or in different combs. On re-use over a number of brood cycles, brood comb becomes a composite material consisting of an elastic element, silk, embedded in a plastic one, wax ; honey-comb tends to remain monophasic. The native silk of brood comb is a hygroscopic, anisotropic, crystalline fibroin whose dry form is structurally superior to its wet state. Dryness of the fibroin is maintained by its incorporation into the wax of the cell wall and possibly by the addition of a size. Anisotropy is exploited by cocoon-spinning larvae which play out the fibre to form sheets of random array. The strength and rigidity of silk is maintained between 25 and $45^{\circ} \mathrm{C}$. Native wax is a hydrophobic, isotropic and paracrystalline plastic whose strength and rigidity greatly decrease with increasing temperature. Propolis, often added to combs, is mechanically similar to wax but structurally inferior to it. The elastic and plastic elements behave very differently with respect to temperature.

Intact brood comb is a planar isotropic silk-wax composite material in which the silk acts as a fibre reinforcement that greatly improves the overall mechanical properties of the comb. With increasing use, the percentage of silk present in the cell walls decreases and so improves the load-bearing capacity of comb. The integrity of the composite is highly dependent on temperature. At $40{ }^{\circ} \mathrm{C}$ the wax phase is a viscous plastic that contributes virtually nothing to the functional composite so that the latter is compromised to the point of failure.

Brood comb, like many composites, is a compromise of the properties of two very different materials which, in combination, provide a structure with qualities that the individual constituents lack. In this instance, the mechanical properties of the composite are extremely sensitive to small changes in 
temperature that naturally occur. Inasmuch as honeybees die in droves at $40^{\circ} \mathrm{C}$ (Free and Spencer-Booth, 1958) and the entire nest is likely to fail at this temperature, the survival of a colony of bees is predicated on thermoregulation. In view of the thermal tolerances operative on maker and material, it would appear that both evolved in a mutualism mediated by thermoregulation.

The compromise of bee and comb at the regulated nest temperature of about $35^{\circ} \mathrm{C}$ may be extended in another direction as well. What honeybees may have gained in improved material performance at a lower temperature, say $25^{\circ} \mathrm{C}$, would have cost them minimally twice as much in expenditure on construction because of the temperature-dependent workability of their materials. Such increased costs would prevail irrespective of losses in the efficiency of energy production and its conversion into useful work. The flexibility attached to self-generated materials with which to build a suspended nest depends on some very finely limited relationships.

Received for publication in November 1986. Accepted for publication in September 1987.

\section{ACKNOWLEDGEMENTS}

We gratefully acknowledge the technical assistance of P.A. Middleton, M. LockHart and S. Murase, and the financial support of the C.S.I.R.

\section{RÉSUMÉ \\ LES RAYONS DE L'ABEILLE, UN MATÉRIAU COMPOSITE}

On a mesuré les changements mécaniques des rayons de l'abeille africaine, Apis mellifica scutellata, en fonction du vieillissement et de la température. La couleur des rayons a varié du blanc au brun et la teneur en soie de 0 à $34 \%$.

Les rayons de couvain, constitués lorsqu'ils sont neufs d'un matériau homogène, la cire pure, se transforment en un matériau hétérogène renforcé en fibres. La fibroïne, protéine crystalline et hygroscopique, est répartie au hasard sur les parois des cellules, les rendant isotropes dans le plan. La fraction de soie a des propriétés mécaniques constantes entre $25^{\circ} \mathrm{C}$ et $45^{\circ} \mathrm{C}$ (Tabl. 1).

Le rayon de cire est une substance plastique isotrope n'ayant aucune constante physique propre (Tabl. 2). La rigidité, la solidité et la résistance à la rupture de la cire des rayons diminuent lorsque la température augmente (Tabl. 2). Lorsque les parois des cellules renferment de la soie, les transformant ainsi en un matériau hétérogène, la stabilité et la solidité sont grandement accrues (Tabl. 2). La fibroïne contribue donc en grande partie à l'unité mécanique des rayons.

Les vieux rayons de couvain sont un compromis entre des matériaux très différents, la cire et la soie, qui, une fois combinés, donnent une structure ayant des propriétés nouvelles différentes de celles de ses constituants (Fig. 1 et 2). 


\section{ZUSAMMENFASSUNG}

\section{DIE WABEN DER HONIGBIENE ALS ZUSAMMENGESETZTES MATERIAL}

Die mechanischen Veränderungen der Waben von afrikanischen Honigbienen, Apis mellifera scutellata, in Beziehung zur Reifung und Temperatur wurden gemessen. Die Farbe der Waben reichte von weiß bis braun und der Seidengehalt variierte von 0 bis $34 \%$.

Frische Brutwaben entwickeln sich aus einem einphasigen Material, reinem Wachs, zu einem faserverstärkten zusammengesetzten Material. Das Fibroin, ein kristallines und hygroskopisches Protein, wird willkürlich über die Zellwand verteilt und macht sie planarisotropisch. Die mechanische Eigenschaften der Seide sind konstant zwischen $25^{\circ} \mathrm{C}$ und $45^{\circ} \mathrm{C}$ (Tab. 1).

Das Wachs der Waben ist ein isotropischer Kunststoff mit keiner einheitlichen mechanischen Konstanten (Tab. 2). Die Steifheit, Stabilität und Bruchfestigkeit des Wabenwachses läßt mit steigender Temperatur nach (Tab. 2). Wenn Seide der Zellwand aufliegt, was diese zu einem zweiphasigen Material macht, so verbessern sich die Wabenstabilität und -steifheit wesentlich (Tab. 2). Auf diese Weise trägt das Fibroin zur Bildung der mechanischen Einheit der Waben bei.

Reife Brutwaben sind also ein Kompromiß zwischen zwei sehr unterschiedlichen Materialen, Wachs und Seide, die als Kombination eine Struktur mit neuen Eigenschaften bilden, die sich von den Eigenschaften der einzelnen Bestandteile unterscheiden (Abb. 1 u. 2).

\section{REFERENCES}

Arnhart L., 1919. - Das Puppenhäuschen der Honigbiene. Z. Ang. Entomol., 5, 231-251.

AtKIns E.D.T., 1967. - A four-stranded coiled-coil model for some insect fibrous proteins. $J$. Mol. Biol., 24, 139-141.

Brewster D., 1815. - Experiments on the depolarisation of light as exhibited by various mineral, animal and vegetable bodies, with a reference to the general principles of polarisation. Philos. Trans. R. Soc. Lond. B., 104, 187-211.

Chauvin R., 1962. - Sur le noircissement des vieilles cires. Ann. Abeille, 5, 59-63.

Denham W.S., Lonsdale T., 1933. - The tensile properties of silk filaments. Trans. Faraday Soc., 29, 305-316.

Free J.B., SPEncer-Booth H.Y., 1958. - Observations on the temperature regulation and food consumption of the honey-bee (Apis mellifica). Entomol. Exp. Appl., 3, 222-230.

HEPBURN H.R., 1986. - Honeybees and wax; an experimental natural history. - Springer, Heidelberg, $205 \mathrm{p}$.

Hepburn H.R., Chander H.D., 1980. - Materials testing of arthropod cuticle preparations. In : Miller T.A. (ed.), Cuticle techniques in arthropods. Springer, New York, Heidelberg, Berlin.

Hepburn H.R., Kurstjens S.P., 1984. - On the strength of propolis (bee glue). Naturwissenschaften, 71, 591-592.

Hepburn H.R., Armstrong E., Kurstjens S.P., 1983. - The ductility of native beeswax is optimally related to honeybee colony temperature. S. Afr. J. Sci., 79, 416-417.

Hepburn H.R., Chander H.D., Davidoff M.R., 1979. - Extensometric properties of insect fibroins : the green lacewing cross-beta, honeybee alpha-helical and greater waxmoth parallel-beta conformations. Insect Biochem., 9, 69-77.

Hepburn H.R., Hugo J.J., Mitchell. D., Nuland M.J.M., Scrimgeour A.G., 1984. - On the energetic costs of wax production by the African honeybee, Apis mellifera adansonii. S. Afr. J. Sci., 80, 363368.

Huber F., 1814. - Nouvelles observations sur les abeilles. 2. translated. 1926 Dadant, Hamilton. 
JAY S.C., 1964. - The cocoon of the honeybee, Apis mellifera L. Can. Entomol., 96, 784-792.

Joffe I., Hepburn H.R., 1974. - A simple low-cost tensometer for biomaterials testing. Experientia, 30, $113-114$

Kurstjens S.P., Hepburn H.R., Schoening F.R.L., Davidson B.C., 1985. - The conversion of wax scales into comb wax by African honeybees. J. Comp. Physiol. B, 156, 95-102.

Lucas F., Rudall K.M., 1968. - Extracellular fibrous proteins : the silks. In : Florkin M., Stotz E.H. (eds), Comprehensive biochemistry. - Elsevier, Amsterdam.

Rudall K.M., 1962. - Silk and other cocoon proteins. In : Florkin M., Mason H.S., (eds), Comparative biochemistry. Academic Press, New York.

ScHMIDr W.J., 1941. - Polarisationsoptische Versuche mit Bienenwachs. Kolloid-Z, 100, 140-151.

Schoening F.R.L., 1980. - The X-ray diffraction pattern and deformation texture of beeswax. S. Afr. J. Sci., 76, 262-265.

Tischer J., 1962. - Über der Herkunft der gelben Farbstoffe des Bienenwachses. Hoppe-Seyler's Z. Physiol. Chem., 267, 14-22.

VerLich A.V., 1930. - Entwicklungsmechanische Studien an Bienenlarven. Z. Wiss. Zool, 136, 210222.

WARWICKER J.O., 1960. - Comparative studies of fibroins-II. The crystal structure of various fibroins. $J$. Mol. Biol., 2, 350-362.

Woog P., Yannaquis N., 1935. - Sur l'orientation des molécules de la cire d'abeille. C.R. Hebd. Séances Acad. Sci. Ser. D Sci. Nat. Paris, 201, 1400-1402.

Woog P., Yannaquis N., 1936a. - Orientation des molécules de la cire d'abeille et répercussion sur la solidité des rayons. C.R. Hebd. Séances Acad. Sci. Ser. D Sci. Nat. Paris, 202, 76-78.

Woog P., Yannaquis N., 1936b. - Orientation des molécules de la cire d'abeille. Répercussions sur la construction des rayons. Arch. Phys. Biol., 13, 134-149. 